Milan Marković ${ }^{1}$

Sandra Milanović ${ }^{2}$

Ivana Marjanović ${ }^{3}$

Innovation Center of the University of Niš
P. 39-48

SCIENTIFIC REVIEW ARTICLE doi:10.5937/ESD1902039M

Received: September, 10, 2019

Accepted: October, 21, 2019

\title{
STRUCTURAL ADJUSTMENT AND SUSTAINABILITY OF AGRICULTURAL PRODUCTION IN SERBIA ${ }^{4}$
}

\begin{abstract}
The starting point in considering the degree of development of agriculture and its sustainability is its production structure. Long-term relationship of crop and animal production in size 2:1 shows that Serbian agriculture is still developing and has not reached the level of developed European countries. The promotion of animal production must be included in every agricultural development policy, as it affects the improvement of the structure of production and exports, the achievement of higher added value, the stability of production, and the increase in capital investments in agriculture. In the assessment of the sustainability of the structure of agricultural production in the Republic of Serbia, the structure of these most important parts of agriculture for the period from 2007 to 2018 was also observed.
\end{abstract}

Key words: sustainability, structural adjustment, agricultural production, crop production, animal production.

Jel classification: Q01, Q13, Q18.

\section{СТРУКТУРНА ПРИЛАГОЂАВАЊА И ОДРЖИВОСТ ПОЉОПРИВРЕДНЕ ПРОИЗВОДЫЕ У СРБИЈИ}

\begin{abstract}
Апстракт
Полазни елемент у разматрағу степена развоја полопривреде и юене одрживости јесте юена производна структура. Дугогодишюи однос биљне и сточарске производье од 2:1 говори о томе да је српска полопривреда још увек у развоју и да није достигла ниво развијених европских земаль. Фаворизоване сточарске производне мора се уктучити у свакој политици развоја пољопривреде, јер она утиче на поболшане структуре производне и извоза, остварене веће додате вредности, стабилност производе, као и повећане капиталних улагаюа у пољопривреди. У проиени одрживости структуре
\end{abstract}

\footnotetext{
${ }^{1}$ markovicmilan89@gmail.com

2 sandramilanovic89@yahoo.com

${ }^{3}$ ivana.veselinovic@eknfak.ni.ac.rs
}

${ }^{4}$ Acknowledgements: The paper is a part of the research done within the project number 179066 ("Improving the Competitiveness of the Public and Private Sector by Networking Competences in the European Integration Process of Serbia") financed by the Ministry of Education, Science and Technological Development of the Republic of Serbia. 
пољопривредне производюе у Републиии Србији посматрана је и структура ових најважнијих делова пољопривреде за период од 2007. до 2018. године.

Клучне речи: одрживост, структурна прилагођаваға, пољопривредна производна, битна производюа, сточарска производюа.

\section{Introduction}

Structural change is a normal evolution in an economy (Goddard, Weersink, Chen, \& Turvey, 1993, p. 476). Continuous economic growth and development is unthinkable without some structural adjustment, which ultimately needs to provide an optimal economic structure. The connection between economic development and the economic structure and structural changes is so obvious and close that even without it economic development (but also agricultural and industrial) cannot be defined (Marjanović, 2015, p. 3).

Under structural changes in agriculture, we mean more participation, or faster growth of certain segments of agriculture. The development of certain branches of agriculture is not uniform, and in this development some branches are lagging behind, while others are developing much faster (Đekić, 2010, p. 150). The strategy of growth and development of the agrarian sector specifies concrete solutions and ways to achieve the stated goals.

The structure of agricultural production is an important indicator of the development not only of agriculture in some country, but also of the entire economy. When it comes to the structure of agricultural output, it refers to the production of agricultural goods and services. As agricultural services make up a very small part of this production, only the main parts of agricultural production will be analysed in the analysis. It is a crop and animal production.

Sustainability of agricultural development imposes the need for an analysis of its structure. Developed countries generally have a higher share of animal production compared to crop production due to the high technology and possibilities of realization of larger investments. Livestock breeding represents the most important and complex structure of agriculture, since for the purpose of nutrition people provide raw materials and have a significant impact on other elements of production, mostly on the production of animal feed (Jovanović, Vučković, \& Pajčin, 2014, p. 196). The livestock industry therefore has great global economic and nutritional significance (Steinfeld, Wassenaar, \& Jutzi, 2006, p. 514). It is a segment that as a rule represents a capital intensive branch of agriculture and is mainly associated with greater ability to attract investments in agriculture. In addition, animal production is also linked to production that has a significantly higher added and market value, and plays an important role in increasing the value of production and exports, as well as improving the structure of the economy and agriculture. Therefore, livestock breeding is important for the stable and harmonious (sustainable) development of total agricultural production, as well as for a more complete and rational use of natural and human resources (Radović, \& Furundžić, 1997, p. 28). 


\section{Methodology and data sources}

In order to prepare a proposal for restructuring the production of agricultural goods, an analytical method was applied. The structure of crop and animal production, as integral parts of agriculture, is considered in detail. SWOT analysis was carried out in order to obtain an overview of the state of agriculture in the Republic of Serbia, while reference secondary data were used to assess the adequacy of the structure of agricultural output production. In addition, agricultural services are neglected, as they make up only $2.5 \%$ of the production of agricultural goods and services. It is a database of the Statistical Office of the Republic of Serbia, as well as the publication Economic Accounts for Agriculture, which is an integral part of the National Accounts System as well as the international statistical system, which provides an assessment of the effects of agricultural policy (Statistical Office of the Republic of Serbia, 2019). The research covered the period from 2007 to 2018, while only 3 representative periods (2007, 2012 and 2017) were taken in certain tables, in order to achieve cost-effectiveness and transparency, as well as easier conclusion based on empirical data.

\section{SWOT analysis and structure of agricultural production in Serbia}

In the study of the necessity of structural changes in agricultural production for its sustainable development, we will start from the so-called SWOT analysis of the agricultural sector of the Republic of Serbia (Table 1).

Table 1: SWOT analysis of the agricultural sector of the Republic of Serbia

\begin{tabular}{|c|c|}
\hline STRENGTHS & WEAKNESSES \\
\hline $\begin{array}{l}\text { - natural wealth } \\
\text { - high quality of human resources } \\
\text { - biodiversity } \\
\text { - production potential } \\
\text { - higher share of agriculture in gross domestic } \\
\text { product in relation to participation in the agrarian } \\
\text { budget } \\
\text { - proximity to the European Union market as the } \\
\text { largest export market }\end{array}$ & $\begin{array}{l}\text { - unfavourable structure of agricultural products } \\
\text { - low productivity } \\
\text { - low level of investment } \\
\text { - fragmentation of the plot } \\
\text { - a small percentage of irrigated areas } \\
\text { - unused production (processing) capacity } \\
\text { - disorganization and low degree of connection } \\
\text { between manufacturers }\end{array}$ \\
\hline OPPORTUNITIES & THREATS \\
\hline $\begin{array}{l}\text { - valorisation of unused capacity } \\
\text { - development of organic production } \\
\text { - multifunctional agriculture } \\
\text { - increasing the agrarian budget due to a more } \\
\text { favourable fiscal situation } \\
\text { - strengthening the cooperation among the } \\
\text { institutes and the universities }\end{array}$ & $\begin{array}{l}\text { - unfavourable demographic trends } \\
\text { - necessary adjustments on the road to the European } \\
\text { Union } \\
\text { - geopolitical events } \\
\text { - threat of cheaper imported products }\end{array}$ \\
\hline
\end{tabular}

Source: Marković, 2018, p. 123

In the basic forces of Serbian agriculture, mainly natural, human and production factors stand out, while the main weaknesses are associated with structural problems. The main dangers arise from insufficient competitiveness of domestic producers, while chances include the development of some parts of agriculture that are the key to its 
development and structural changes in production in the future (livestock and organic production).

Table 2: Production of agricultural goods in the Republic of Serbia, current prices (in millions of RSD)

\begin{tabular}{|l|c|c|c|c|c|c|}
\hline \multirow{2}{*}{$\begin{array}{c}\text { Production of } \\
\text { agricultural goods }\end{array}$} & \multicolumn{2}{|c|}{ 2007. } & \multicolumn{2}{c|}{2012.} & \multicolumn{2}{c|}{2017.} \\
\cline { 2 - 6 } & Value & Participation & Value & Participation & Value & Participation \\
\hline Crop production & 217.274 & $67,74 \%$ & 324.451 & $66,00 \%$ & 357.056 & $67,38 \%$ \\
\hline Animal production & 103.482 & $32,26 \%$ & 167.146 & $34,00 \%$ & 172.834 & $32,62 \%$ \\
\hline TOTAL & 320.756 & $100 \%$ & 491.597 & $100 \%$ & 529.890 & $100 \%$ \\
\hline
\end{tabular}

Source: Statistical Office of the Republic of Serbia, 2019.

Observing Table 2, it can be seen that in analysed years, and practically it can be said in the entire period from 2007 to 2017, a stable relationship between crop and livestock production in the overall structure is evident. A slight improvement in the structure of agricultural production occurred in 2012. However, this improvement is the result of unfavourable climatic factors that have resulted in a drastic fall in crop production. The value of agricultural production has grown steadily in the analysed period. Crop production increased by $64.33 \%$ compared to the base year of 2007 , and the value of animal production increased by $67.02 \%$.

Regarding the region, only North Macedonia has more share of crop production in total agricultural production than in Serbia (Gajić, \& Zekić, 2013, p. 77). In the countries of the European Union, the situation is also completely different in relation to the Republic of Serbia, because animal production is twice as high as the value of crop production. Crop production in the Republic of Serbia is mostly done in an open area, which increases the dependence on climate factors and makes it extensive.

\section{Structure of crop and animal production in Serbia}

In order to initiate serious changes in the structure of agricultural production, it is necessary to increase the participation of animal production, but also to encourage the production of certain groups of products within the framework of the crop production itself. The structure of crop production is shown exactly in Table 3.

Table 3: Structure of the value of crop production in the Republic of Serbia, current prices (in millions of RSD)

\begin{tabular}{|l|r|c|r|r|r|c|}
\hline \multirow{2}{*}{$\begin{array}{l}\text { Parts of crop } \\
\text { production }\end{array}$} & \multicolumn{2}{|c|}{ 2007. } & \multicolumn{2}{c|}{2012.} & \multicolumn{2}{c|}{2017.} \\
\cline { 2 - 7 } & \multicolumn{1}{|c|}{ Value } & Participation & \multicolumn{1}{c|}{ Value } & Participation & Value & Participation \\
\hline Cereals (including seed) & 90.749 & $41,77 \%$ & 138.325 & $42,63 \%$ & 113.760 & $31,86 \%$ \\
\hline Industrial crops & 26.549 & $12,22 \%$ & 52.806 & $16,28 \%$ & 58.444 & $16,37 \%$ \\
\hline Forage plants & 12.761 & $5,87 \%$ & 18.693 & $5,76 \%$ & 20.985 & $5,88 \%$ \\
\hline $\begin{array}{l}\text { Vegetables and } \\
\text { horticultural products }\end{array}$ & 22.585 & $10,39 \%$ & 28.985 & $8,93 \%$ & 32.538 & $9,11 \%$ \\
\hline
\end{tabular}




\begin{tabular}{|l|r|c|r|r|r|c|}
\hline Potato & 8.318 & $3,83 \%$ & 12.342 & $3,80 \%$ & 11.687 & $3,27 \%$ \\
\hline Fruits & 33.929 & $15,62 \%$ & 53.932 & $16,62 \%$ & 76.995 & $21,56 \%$ \\
\hline Wine & 21.796 & $10,03 \%$ & 18.925 & $5,83 \%$ & 42.112 & $11,79 \%$ \\
\hline Olive oil & - & $0 \%$ & - & $0 \%$ & - & $0 \%$ \\
\hline Other crop products & 587 & $0,27 \%$ & 443 & $0,14 \%$ & 538 & $0,15 \%$ \\
\hline TOTAL & $\mathbf{2 1 7 . 2 7 4}$ & $\mathbf{1 0 0} \%$ & $\mathbf{3 2 4 . 4 5 1}$ & $\mathbf{1 0 0} \%$ & $\mathbf{3 5 7 . 0 5 6}$ & $\mathbf{1 0 0} \%$ \\
\hline
\end{tabular}

Source: Statistical Office of the Republic of Serbia, 2019.

The key consideration is that the structure of plant production is improved, bearing in mind that the share of fruits and industrial plants has increased. These are the branches of agriculture that can be the bearers of structural changes and the increase in the value of final products, if the benefits of individual areas are used for their profitable production. However, although the share of cereals has been reduced, there is a problem because the absolute value of production of this most frequent branches of the crop production, in the total value of production, has also decreased. The production of wine is after a certain reduction, again from 2017 on the percentage of participation from 2007, which is a positive fact from the aspect of improving the structure of production with higher added value.

Table 4 gives an overview of the structure of animal production for selected years (2007, 2012 and 2017). Production of pigs and milk is dominated by animal production, while the structure of other segments is very stable over time. The participation of cattle production must be the backbone of the animal production development.

Table 4: Structure of value of animal production in the Republic of Serbia, current prices (in millions of RSD)

\begin{tabular}{|l|r|c|r|r|r|c|}
\hline \multirow{2}{*}{$\begin{array}{l}\text { Parts of animal } \\
\text { production }\end{array}$} & \multicolumn{2}{|c|}{ 2007. } & \multicolumn{2}{c|}{$\mathbf{2 0 1 2 .}$} & \multicolumn{2}{c|}{$\mathbf{2 0 1 7 .}$} \\
\cline { 2 - 7 } & Value & Participation & Value & Participation & Value & Participation \\
\hline Cattle & 21.439 & $20,72 \%$ & 29.059 & $19,37 \%$ & 31.703 & $18,75 \%$ \\
\hline Pigs & 32.955 & $31,85 \%$ & 48.768 & $32,51 \%$ & 57.098 & $33,78 \%$ \\
\hline Equines & 128 & $0,12 \%$ & 61 & $0,04 \%$ & 77 & $0,05 \%$ \\
\hline $\begin{array}{l}\text { Sheep and } \\
\text { goats }\end{array}$ & 6.524 & $6,30 \%$ & 9.315 & $6,21 \%$ & 8.971 & $5,31 \%$ \\
\hline Poultry & 7.954 & $7,69 \%$ & 15.572 & $10,38 \%$ & 13.163 & $7,79 \%$ \\
\hline Other animals & - & $0 \%$ & - & $0 \%$ & & $0 \%$ \\
\hline Milk & 25.352 & $24,50 \%$ & 34.212 & $22,80 \%$ & 37.310 & $22,07 \%$ \\
\hline Eggs & 8.288 & $8,01 \%$ & 10.810 & $7,21 \%$ & 15.507 & $9,17 \%$ \\
\hline $\begin{array}{l}\text { Other animal } \\
\text { products }\end{array}$ & 842 & $0,81 \%$ & 2.226 & $1,48 \%$ & 5.216 & $3,09 \%$ \\
\hline TOTAL & $\mathbf{1 0 3 . 4 8 2}$ & $\mathbf{1 0 0} \%$ & $\mathbf{1 5 0 . 0 2 2}$ & $\mathbf{1 0 0} \%$ & $\mathbf{1 6 9 . 0 4 6}$ & $\mathbf{1 0 0 \%}$ \\
\hline
\end{tabular}

Source: Statistical Office of the Republic of Serbia, 2019.

\section{The importance of animal production and structural changes}

Factors that affect the state of well-being and movements in animal production are: its extensive character, low specialization and a combination of animal and crop 
production, the collapse of cooperatives, privatization and deterioration of agricultural combines, as well as slaughterhouses and dairies (Mićić, 2016, p. 199). For the propulsive development of animal production, it is necessary to work on breeding quality breeds of cattle and to strengthen the processing capacities. On the other hand, Đekić (2010, p. 150 ) points out that the increase in the ability to pay is a prerequisite for higher animal production.

However, insufficient volume of investments in agriculture, and consequently low productivity, affects the permanent reduction of animal in the Republic of Serbia. On the basis of Table 5, there is a continuous decline in the number of cattle and pigs. The number of cattle decreased by $19.23 \%$ for the period from 2007 to 2018 , while the number of pigs in the same period decreased by as much as $27.40 \%$. Therefore, in addition to increasing imports of these products, there is a danger of falling export-oriented production.

Table 5: Balance of livestock in the Republic of Serbia from 2007 to 2018 (end of the period)

\begin{tabular}{|l|r|r|r|r|}
\hline \multicolumn{1}{|c|}{ Year } & Cattle & Pigs & Sheep & Poultry \\
\hline 2007. & 1087 & 3832 & 1606 & 16422 \\
\hline 2008. & 1057 & 3594 & 1605 & 17188 \\
\hline 2009. & 1002 & 3631 & 1504 & 22821 \\
\hline 2010. & 938 & 3489 & 1475 & 20156 \\
\hline 2011. & 937 & 3287 & 1460 & 19103 \\
\hline 2012. & 921 & 3139 & 1635 & 18234 \\
\hline 2013. & 913 & 3144 & 1616 & 17860 \\
\hline 2014. & 920 & 3236 & 1748 & 17167 \\
\hline 2015. & 916 & 3284 & 1789 & 17450 \\
\hline 2016. & 893 & 3021 & 1665 & 16242 \\
\hline 2017. & 899 & 2911 & 1704 & 16338 \\
\hline 2018. & 878 & 2782 & 1712 & 16232 \\
\hline
\end{tabular}

Source: Statistical Office of the Republic of Serbia, 2019a.

Another reason contributing to animal production is its lower instability compared to crop production. This means that a greater degree of continuity in satisfying domestic and foreign demand can be achieved. Low level and incomplete application of agrotechnical measures in crop production, a small percentage of irrigated areas, insufficient genetic potential and unbalanced livestock nutrition have significant effects on oscillations in crop and animal production (Strategy of Agriculture and Rural Development of the Republic of Serbia 2014-2024, 2014, p. 21). This is especially characteristic for crop production. Chart 1 testifies to this. 
Chart 1: Rates of change in the value of crop, animal and production of agricultural goods in the Republic of Serbia (producer prices of the current year)

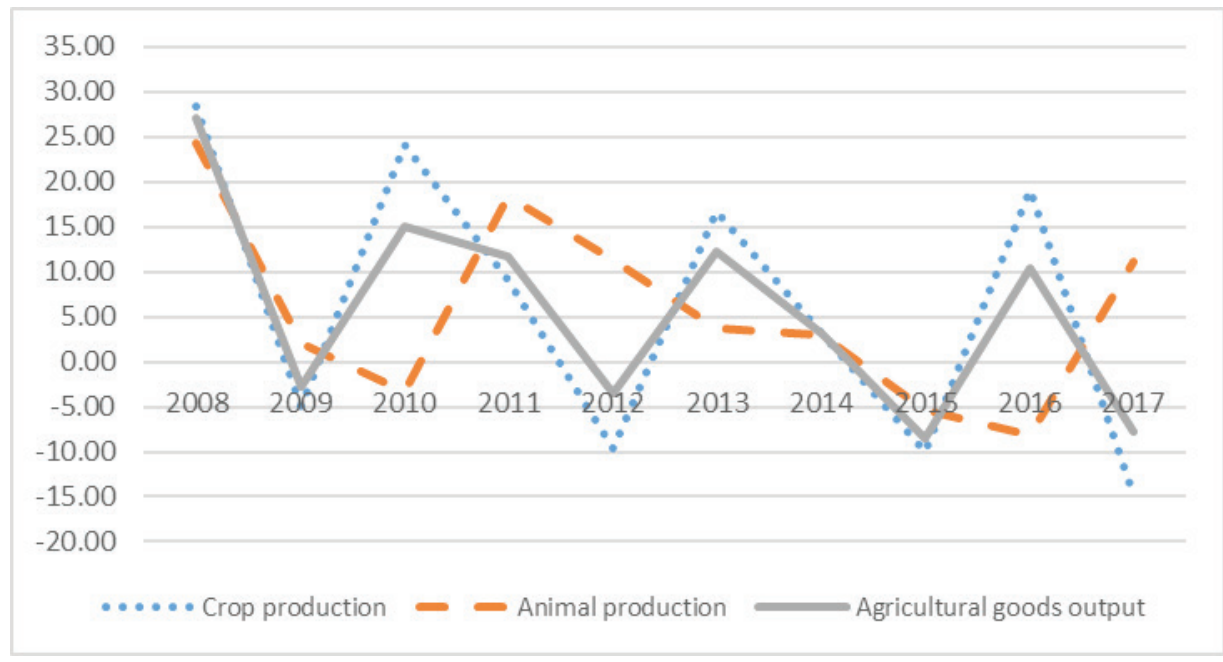

Source: Authors' presentation based on the data of the Statistical Office of the Republic of Serbia, 2019.

The need for favouring animal production is also due to the fact that it is a product that achieves a significantly higher value on the market. The ability to create greater added value through their processing is an essential element in increasing the degree of finalization of agricultural products. Livestock produce food, provide security, enhance crop production, generate cash incomes for rural and urban populations, provide fuel and transport, and produce value added goods which can have multiplier effects and create a need for services (Seré, Steinfeld, \& Groenewold, 1996, p. 2).

In addition, animal production requires significant investments in equipment, construction of auxiliary facilities and the like, so it is also related to the development of other activities. It is a capital intensive branch of agriculture. Without the development of livestock, Serbian agriculture will remain an exporter of cheap raw materials, which from the aspect of the needs of the development of the food industry is an unacceptable solution (Post-crisis model of economic growth and development of Serbia 2011-2020, 2010, p. 32). Crop production mostly relies on arable land as a basic resource in agriculture, which leads to cheap production and exports. This will produce at a macro level a poor production-export structure, as well as a deterioration of the balance of payments. On the other hand, at the micro level, the majority production of primary products will cause a bad economic status of farmers. In this way, small farms will not have the ability to borrow in the form of loans. Livestock diversify production and income, provide year-round employment, spread risk, and also form a major capital reserve of farming households (Seré, Steinfeld, \& Groenewold, 1996, p. 2).

Intensification will provide better production results: yields will be higher, more land will be irrigated and become arable (Alexandratos, 1995). In addition, it is necessary to adjust the assortment and specialize the production of farms. In developed countries, this can be seen today through the development of large, specialized animal production units in broiler, dairy or pork production (which contrast with the more traditional mixed crop-animal farms) (Chavas, 2001, p. 266). 
Agricultural policy, which will stimulate the change of crop production structure, respecting, support for investing in more intensive production (truck farming, fruit growing, viticulture), as well as increasing the total livestock, is necessary, in order to get greater effects by agriculture (Kuzman, Đurić, Mitrović, \& Prodanović, 2017, p. 524). Because of the character of agricultural production, these changes and adjustments cannot be implemented in the short term, so that the creators of agrarian policy must take this into account when working in this field.

\section{Conclusion}

Structural changes in agricultural production are importantboth for the development of the agri-food sector, as well as for overall economic growth and development, as they increase competitiveness and improve the balance of payments situation. Through the achievement of livestock breeding, sustainable growth of agricultural production will be enabled, which, in addition to the economic effect, will also have social and demographic effects, and will result in overall socio-economic development. Long-term measures of agrarian policy must not neglect animal production, as was the case in the past.

The dominant share of crop production in the structure of agricultural production (around 66\%) is an indicator of the still underdeveloped agriculture in which the natural production and fragmentation of landholdings. The intensification of agricultural production should enable greater production of meat, milk and other animal products. The emphasis on higher relative share of animal production should not mean a reduction in crop production, but also its absolute growth in order to increase the total value of agricultural goods. For that purpose, investment in refrigerators, dryers and silos, as well as product standardization, can play a major role (Simonović, Mihailović, \& Janković, 2017). Cereal production should have an upward trend in view of the built position in the foreign market. The fruit production is rising due to the increase in the level of technology being applied. In accordance with the goals of sustainable agricultural development, it is necessary to increase the organic production share, primarily organic animal production.

\section{References}

Alexandratos, N. (Ed.). (1995). World agriculture: towards 2010; an FAO study. Food \& Agriculture Org.

Chavas, J. P. (2001). Structural change in agricultural production: economics, technology and policy. Handbook of agricultural economics, 1, 263-285.

Gajić, M., \& Zekić, S. (2013). Development characteristics of agricultural sector in Serbia. In Škorić, D., Tomić, D., Popović, V. (Eds.): AGRI-FOOD SECTOR IN SERBIA - STATE AND CHALLENGES (pp. 73-90). Belgrade: Serbian Association of Agricultural Economics.

Goddard, E., Weersink, A., Chen, K., \& Turvey, C. G. (1993). Economics of structural change in agriculture. Canadian Journal of Agricultural Economics/Revue canadienne d'agroeconomie, 41(4), 475-489. 
Đekić, S. (2010). Agrarni menadžment [Agrarian management]. Niš: Ekonomski fakultet Univerziteta u Nišu.

Jovanović, M., Vučković, S., \& Pajčin, Đ. (2014). Proizvodnja krmnog bilja kao osnova održivog razvoja poljoprivrede Srbije [Production of fodder plants as the basis for sustainable development of agriculture in Serbia]. Ekonomika, 60(3), 195-203.

Kuzman, B., Djurić, K., Mitrović, L., \& Prodanović, R. (2017). Agricultural budget and agriculture development in Republic of Serbia. Economics of Agriculture, 64(2), 515-531.

Marjanović, V. (2015). Strukturne promene i privredni razvoj [Structural changes and economic development]. Niš: Ekonomski fakultet Univerziteta u Nišu.

Marković, M. (2018). Uloga poljoprivredno-prehrambenog sektora u povećanju izvoza Republike Srbije [The role of the agri-food sector in increasing the export of the Republic of Serbia]. Doktorska disertacija. Niš: Ekonomski fakultet Univerziteta u Nišu.

Mićić, V. (2016). Izazovi razvoja agroprehrambene industrije Republike Srbije [Challenges of the development of the agri-food industry of the Republic of Serbia]. U Leković, V. (red.): Naučni skup: Institucionalne promene kao determinanta privrednog razvoja Republike Srbije, (pp. 191-209). Kragujevac: Ekonomski fakultet Univerziteta u Kragujevcu.

Pejanović, L. (2015). Polution of basic natural resources with hazardous matters. Ekonomika poljoprivrede, 62(4), 1095-1107.

Post-crisis model of economic growth and development of Serbia 2011-2020 (2010). USAID i Fond za razvoj ekonomske nauke [USAID and the Economic Science Development Fund]. Available at:_http://www.kss.org.rs/doc/1102_ makroekonomska_proj_razv_Srbije_2011-2020.pdf Retrieved: 10/12/2018.

Radović, I., \& Furundžić, M. (1997). Principi i metode organizacije i ekonomike poljoprivredne proizvodnje [Principles and methods of organization and economics of agricultural production]. Beograd: VELARTA.

Seré, C., Steinfeld, H., \& Groenewold, J. (1996). World livestock production systems. Food and Agriculture Organization of the United Nations

Simonović, Z., Mihailović, B., \& Janković, M. (2017). Usmeravanje poljoprivredne proizvodnje u Srbiji i održivost njenog razvoja [Directing agricultural production in Serbia and sustainability of its development]. Economics of Sustainable Development, 1(1), 19-32.

Statistical Office of the Republic of Serbia (2019). Ekonomski računi poljoprivrede u Republici Srbiji 2007-2017 [Economic accounts for agriculture in the Republic of Serbia 2007-2017], Available at: http://www.stat.gov.rs/oblasti/nacionalni-racuni/ ekonomski-racuni-poljoprivrede/ Retrieved: 18/06/2019.

Statistical Office of the Republic of Serbia (2019a). Baza podataka [Database], Available at: http://data.stat.gov.rs/Home/Result/1302020101 ?languageCode=srLatn Retrieved: 23/06/2019.

Steinfeld, H., Wassenaar, T., \& Jutzi, S. (2006). Livestock production systems in developing countries: status, drivers, trends. Rev Sci Tech, 25(2), 505-516. 
Strategy of Agriculture and Rural Development of the Republic of Serbia 2014-2024. (2014). Vlada Republike Srbije [Government of the Republic of Serbia]. Available at: http://uap.gov.rs/wp-content/uploads/2016/05/STRATEGIJA-2014-2020-.pdf Retrieved: 22/06/2019. 